\title{
THE USE OF ONLINE COLLABORATIVE WRITING TOOLS BY Ph.D. STUDENTS
}

\author{
Dalbert Marques Oliveira ${ }^{1}$, Ana Lúcia Terra ${ }^{2}$ \\ ${ }^{1}$ Faculdade de Letras da Universidade de Coimbra, dalbertoliveira@ gmail.com, ORCiD iD 0000-0001-9035- \\ 3480 \\ ${ }^{2}$ Faculdade de Letras da Universidade de Coimbra, anaterra@fl.uc.pt, ORCiD iD 0000-0003-1292-2849
}

\begin{abstract}
One of the characteristics of personal knowledge management is sharing this knowledge with peers, which can also be accomplished through tools. That said, this work communicates an empirical investigation that explored the use of online collaborative writing tools (OCW), by individuals as students of two programs in the field of Information Sciences in Portugal, intending to know, the point of view about OCWs throughout this cycle of studies. These objectives were achieved through a mixed methodology, using an exploratory and research approach. As research techniques, a bibliography and a questionnaire were used. It was observed the majority use of three OCWs, considered important for the academic path. On the other hand, it seems that the aforementioned doctoral programs could contribute more actively to the use of these OCW. This work intends to inform other investigations about the students' relationship with the OCW, collaborate so that the students themselves become aware of these tools, and contribute with the educational programs to rethink the practices that support this use.
\end{abstract}

Palavras-chave: Online collaborative writing tools, Personal Knowledge Management, Ph.D. students

\section{INTRODUCTION}

This work is limited to the use of online collaborative writing tools (OCW) by individuals as students of two doctoral programs: the Doctoral Program in Information Science at the University of Coimbra (PDCI); and the Doctoral Program in Information and Communication on Digital Information Platforms (ICPD), taught jointly by the University of Porto and the University of Aveiro.

Researchers like Ngulube (2015) comment on the scarcity of empirical studies with clear methodologies related to knowledge management, which also seems to apply to personal knowledge management (PKM). On the other hand, there are still few investigations that address the use of OCW by Ph.D. students (M. M. C. Gallotti, 2017).

On the other hand, it is possible to find works that information about the use of technological tools for the PKM (Ismail \& Ahmad, 2015; Liu et al., 2017; Razmerita et al., 2009) and OCW, mainly those that are part of the Google application suite, inserted in Google Drive, and Microsoft, inserted in the old Office Live, and currently in OneDrive, Office 365 and Teams, both in basic and university education (Abrams, 2016; Brescó Baiges \& Verdú Surroca, 2014; Castellanos Sánchez \& Martínez de la Muela, 2013; Miseviciene et al., 2011; Naik et al., 2013; Oliveira \& Terra, 2021; Rienzo \& Han, 2009; Srba, 2010).

In addition to the OCW from Google and Microsoft, it is possible to find works that mention other platforms and tools that allow collaborative writing online, such as Wiki (Cilliers, 2017), blogs (Garcia et al., 2019), Skype (Akbaba \& Başkan, 2017), EtherPad (Olson et al., 2017), Dropbox (Hunsinger \& Corley, 2012), Manuscripts.io, Overleaf and Authorea (Pepe et al., 2020). These tools are sometimes used for collaborative writing, sometimes as a complement to this writing (cf. Boellstorff et al., 2013).

In spite of the fact that several errors are found in the use of these OCW (Ahmed-Nacer et al., 2013; cf. Brescó Baiges \& Verdú Surroca, 2014; cf. Oliveira \& Terra, 2021; cf. Olson et al., 2017). The common 


\section{ISKO 2021 LISBOA}

RESUMO

denominator found by these authors seems to be the ease of interaction between different elements of a group in sharing and editing information to achieve a common goal.

That said, the objectives of this work are to know the relationship of individuals, as students, with OCW, to know which OCWs are most popular for students, how and with which they use them, who influence them in this use, and the point of view of these students on the role of these programs in the use of OCW.

These objectives were achieved through a constructivist paradigm (Guba \& Lincoln, 1994) using an exploratory and descriptive approach (Ngulube, 2015) and a mixed methodology, using research as a quantitative approach (Gil, 2008), and the exploration of literature as a qualitative approach (Lakatos \& Marconi, 2007).

It was observed that the respondents mostly use three OCWs, mostly with their peers from the same institution, who suffer greater influences from the teachers and who consider the OCWs important for the academic path. Finally, they believe that the aforementioned doctoral programs could contribute more actively to the use of these OCW.

\section{METHODOLOGY}

In the literature review carried out for this work, it was possible to observe that there are studies on the use of OCW by students of different educational levels. All of these studies comment that these tools are an asset in education. In turn, the literature related to the use of OCW by students of Ph.D. programs is still scarce (cf. M. M. C. Gallotti, 2017).

On the other hand, there are several OCW available on the market, which have several resources (cf. Rienzo \& Han, 2009). Furthermore, there are studies that comment on some flaws that these tools can present during use.

That said, this work aims to explore the use of OCW by individuals as students of PDCI and ICPD. Therefore, the objectives of the investigation are:

- Know which OCW's are most popular for PDCI students?

- How and with whom do these students use them?

- Who has an influence on this use?

- What is the role of institutions in using OCW?

In order to face these questions, this work starts from a constructivist paradigm (Guba \& Lincoln, 1994), using a mixed methodology that uses research, as a quantitative approach, and the exploration of literature as a qualitative approach (Gil, 2008; Lakatos \& Marconi, 2007). As research methods, the bibliographic was used, through a literature review (Webster \& Watson, 2002), justifying the construction of a questionnaire.

The sample was obtained through contact with class representatives, through group publications of the referred programs on Facebook, through direct contact with students, and through the institutional email sent by the course coordinators to students and graduates.

\section{RESULTS}

47 responses were obtained, which corresponds to just over $14 \%$ of the investigated population. Using a 95\% confidence interval, this sample has a margin of error of 13.3\% (Levin, 1987). Among these 47 respondents, 39 declared they used OCW during their doctorate.

Of these 39 respondents, 92\% reported using Google Drive, 61.5\% Dropbox Paper and 48.7\% using Microsoft tools. The choice for Google Drive seems to be related to factors such as the greater recognition of this platform, in relation to others, in relation to its connection with other tools: "[I use] Google Docs 


\section{ISKO 2021 LISBOA}

RESUMO

because it integrates the reference manager Zotero"; and the practicality of use: [I use] "Google Docs and Sheets, as it is common and practical". This preference can also be observed in the study by Gallotti (2017).

The influence to use OCW comes mostly from teachers who influenced $48.7 \%$ of respondents, followed by colleagues or researchers who influenced $38.5 \%$ of respondents. However, $33.3 \%$ of respondents stated that they had not been influenced by the use of OCW.

With regard to the collaborative use of OCW $66.7 \%$ of respondents said they used OCW with classmates/coursemates, $48.7 \%$ with colleagues/researchers from the same institution. Tied with $33.3 \%$ of respondents, there are those with colleagues/researchers from other national and international institutions.

On the other hand, when a cut is made on the role played by the doctoral program in encouraging the use of OCW, it is observed that the "mode" of these responses seems to suggest that doctoral programs play an average role in encouraging this use.

In spite of the fact that teachers were elected as the greatest influence in the use of OCW, it seems that the programs could have a more active role, as suggested by one of the respondents: "The Ph.D. programs in IC and Communication could take courses about using OCW tools, something I didn't see in my Ph.D.".

Otherwise, the "mode" of the responses regarding the importance of using OCW for success in the Ph.D. course, seems to demonstrate that this use is considered to be very important.

In fact, the comments of some respondents show this importance. One participant commented: "I believe that tools such as OWC are important for doctoral students because they greatly assist scientific communication. These are elements that are already internalized in the doctoral research cycle".

Finally, failures in the use of OCW were reported by $31 \%$ of respondents. Among these failures, mention was made of "data loss due to synchronization failure"; "slowness, which discouraged use"; limitations "with regard to the use of styles for paragraphs/titles and the absence of a tool to insert captions in figures (both cases it is possible to overcome the issue using third-party ad-ons)"; The loss of formatting of the document between platforms: "formatting is not always replicable for Microsoft Word, but nothing that invalidates its study"; which includes "export errors and word compatibility errors".

These flaws are similar to those reported by users of these OCW (Jackson 203, 2019; Leme, 2016; Sarton85, 2011), by students from several countries (Oliveira \& Terra, 2021), and authors like Brescó Baiges and Verdú Surroca (2014), Ahmed-Nacer et al. (2013) and Olson, et al. (2017).

\section{CONCLUSIONS}

In this investigation, it was possible to explore the importance of OCW in the Ph.D. course. It was observed that there is a set of OCWs most used by the study respondents and that on the one hand, OCWs are very useful for the Ph.D. course, but on the other hand, these programs should more actively promote this use.

Otherwise, it was possible to observe that some care is needed in the use of OCW. Synchronization failures have been identified that appear to be linked to the recording intervals of the OCW itself, which can cause conflicts when two or more people are editing the same document at the same time; formatting errors were also observed, especially when using the same document with different OCW.

That said, it is important to note that this study had a limitation, which translates into the reduced number of respondents, mainly by the ICPD, which produced a margin of error of more than about $13 \%$, for a confidence index of $95 \%$. This margin of error can negatively affect the study.

It is hoped that this study can provide an insight into the use of OCW by students in the investigated doctoral programs; inform about the possibilities of these tools for sharing personal knowledge; encourage 


\section{ISKO 2021 LISBOA}

RESUMO

its use by those who do not yet use OCW; and to encourage the said Doctoral Programs to approach and build explanatory courses on the use of these OCW tools.

Finally, this work did not address the different dimensions of using OCW, which includes the resources

most used by these students and which of these resources can contribute to the management of personal knowledge. Future studies can address these issues.

\section{REFERENCES}

Abrams, Z. (2016). Exploring collaboratively written L2 texts among first-year learners of German in Google Docs. Computer Assisted Language Learning, 29(8), 1259-1270. https://doi.org/10.1080/09588221.2016.1270968

Ahmed-Nacer, M., Urso, P., Balegas, V., \& Preguiça, N. (2013). Concurrency control and awareness support for multi-synchronous collaborative editing. 9th IEEE International Conference on Collaborative Computing: Networking, Applications and Worksharing, 148-157. https://doi.org/10.4108/icst.collaboratecom.2013.254113

Akbaba, Y., \& Başkan, F. (2017). How to merge courses via Skype ${ }^{\mathrm{TM}}$ ? Lessons from an International Blended Learning Project. Research in Learning Technology, 25(0). https://doi.org/10.25304/rlt.v25.1915

Boellstorff, T., Nardi, B., Pearce, C., \& Taylor, T. L. (2013). Words with friends: Writing collaboratively online. Interactions, 20(5), 58-61. https://doi.org/10.1145/2501987

Brescó Baiges, E., \& Verdú Surroca, N. (2014). Valoración del uso de las herramientas colaborativas Wikispaces y Google Drive, en la educación superior. https://repositorio.minedu.gob.pe/handle/20.500.12799/3189

Castellanos Sánchez, A., \& Martínez de la Muela, A. (2013). Trabajo en equipo con Google Drive en la universidad online. Innovación educativa (México, DF), 13(63), 75-94.

Cilliers, L. (2017). Wiki acceptance by university students to improve collaboration in higher education. Innovations in Education and Teaching International, 54(5), 485-493. https://doi.org/10.1080/14703297.2016.1180255

Gallotti, M. M. C. (2017). Práticas de Comunicação Científica de Doutorandos em Ciência da Informação no Espaço Ibérico e no Brasil: Um estudo exploratório (Repositório Aberto da UP). https://doi.org/10.13140/RG.2.2.11097.47205

Garcia, E., Moizer, J., Wilkins, S., \& Haddoud, M. Y. (2019). Student learning in higher education through blogging in the classroom. Computers \& Education, 136, 61-74. https://doi.org/10.1016/j.compedu.2019.03.011

Gil, A. C. (2008). Métodos e técnicas de pesquisa social (6 $\left.6^{\mathrm{a}}\right)$. Editora Atlas S.A. https://biblioteca.isced.ac.mz:443/handle/123456789/707

Guba, E. G., \& Lincoln, Y. S. (1994). Competing paradigms in qualitative research. Em Handbook of qualitative research (pp. 105-117). Sage Publications, Inc.

Hunsinger, D. S., \& Corley, J. K. (2012). An Examination of the Factors Influencing Student Usage of Dropbox, a File Hosting Service. Proceedings of the Conference on Information Systems Applied Research, 5, 1-8. https://citeseerx.ist.psu.edu/viewdoc/download?doi=10.1.1.462.3946\&rep=rep1\&type=pdf

Ismail, S., \& Ahmad, M. S. (2015). Personal Knowledge Management among Managers: Mobile Apps for Collective Decision Making. Journal of Information Systems Research and Innovation, 9(1), 4229.

Jackson 203, R. (2019, Abril 17). Formatting Issues when uploading Word docs in .docx format [Community]. Docs Editor Help. https://support.google.com/docs/thread/4313531?hl=en

Lakatos, E. M., \& Marconi, M. de A. (2007). Metodologia do trabalho científico: Procedimentos básicos; pesquisa bibliográfica, projeto e relatório; publicações e trabalhos científicos ( $7^{\mathrm{a}}$ edição). Atlas.

Leme, C. (2016, Fevereiro 29). Word 2013 perde formatação em outras versões. Microsoft Community. 


\section{ISKO 2021 LISBOA}

RESUMO

https://answers.microsoft.com/pt-br/msoffice/forum/msoffice_word-mso_windows8-

mso_2013_release/word-2013-perde-formata\%c3\%a7\%c3\%a3o-em-outras/44c3e0fe-78c2-48489426-04fa1e10f5bb

Levin, J. (1987). Estatistica aplicada a ciências humanas (2a). Harbra.

Liu, C.-H., Wang, J. S., \& Lin, C.-W. (2017). The concepts of big data applied in personal knowledge management. Journal of Knowledge Management, 21(1), 213-230. https://doi.org/10.1108/JKM07-2015-0298

Miseviciene, R., Budnikas, G., \& Ambraziene, D. (2011). Application of Cloud Computing at KTU: MS Live@Edu Case. Informatics in Education, 10(2), 259-270.

Naik, A., Ajay, A. K., \& Kolhatkar, S. S. (2013). Applicability of cloud computing in academia. Indian Journal of Computer Science and Engineering, 4(1), 11-15.

Ngulube, P. (2015). Trends in Research Methodological Procedures used in Knowledge Management Studies (2009 - 2013). African Journal of Library, Archives and Information Science, 24(2), 125143. https://doi.org/10.13140/RG.2.1.2778.4162

Oliveira, D. M., \& Terra, A. L. (2021). Online and Collaborative Tools During Academic and Erasmus Studies. Em R. Babo, N. Dey, \& A. S. Ashour (Eds.), Workgroups eAssessment: Planning, Implementing and Analysing Frameworks (pp. 85-115). Springer. https://doi.org/10.1007/978981-15-9908-8_4

Olson, J. S., Wang, D., Olson, G. M., \& Zhang, J. (2017). How People Write Together Now: Beginning the Investigation with Advanced Undergraduates in a Project Course. ACM Transactions on Computer-Human Interaction, 24(1), 4:1-4:40. https://doi.org/10.1145/3038919

Pepe, A., Cavalleri, M., Best, B. D., Olivotto, V., \& Cantiello, M. (2020). Scientific collaboration in the era of COVID-19 [Preprint]. Preprints. https://doi.org/10.22541/au.158826951.14028294/v2

Razmerita, L., Kirchner, K., \& Sudzina, F. (2009). Personal knowledge management: The role of Web 2.0 tools for managing knowledge at individual and organisational levels. Online Information Review, 33(6), 1021-1039. https://doi.org/10.1108/14684520911010981

Rienzo, T., \& Han, B. (2009). Teaching Tip: Microsoft or Google Web 2.0 Tools for Course Management. Journal of Information Systems Education, 20(2), 123-128.

Sarton85. (2011, Novembro 16). Why is the layout of text in Google Documents inconsistent between browsers? And what to do about it? [Community]. Docs Editor Help. https://support.google.com/docs/forum/AAAABuH1jm0dqRzrdJMBM8/?hl=en

Srba, J. (2010). An experiment with using Google tools for project supervision at tertiary education. Proceedings of the 11th International Conference on Computer Systems and Technologies and Workshop for PhD Students in Computing on International Conference on Computer Systems and Technologies - CompSysTech '10, 430. https://doi.org/10.1145/1839379.1839455

Webster, J., \& Watson, R. T. (2002). Analyzing the Past to Prepare for the Future: Writing a Literature Review. MIS Quarterly, 26(2), xiii-xxiii. 